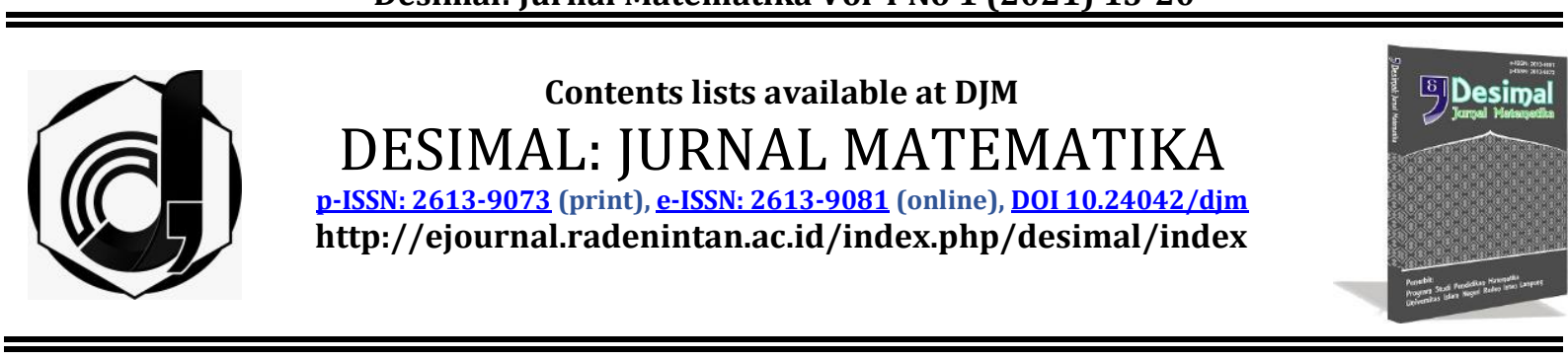

\title{
Visual, auditory, and kinesthetic learning model on the mathematics problem solving ability
}

\author{
Oktavia Nadia Ikawati*, Kowiyah \\ Universitas Muhammadiyah Prof. Dr. Hamka, Indonesia
}

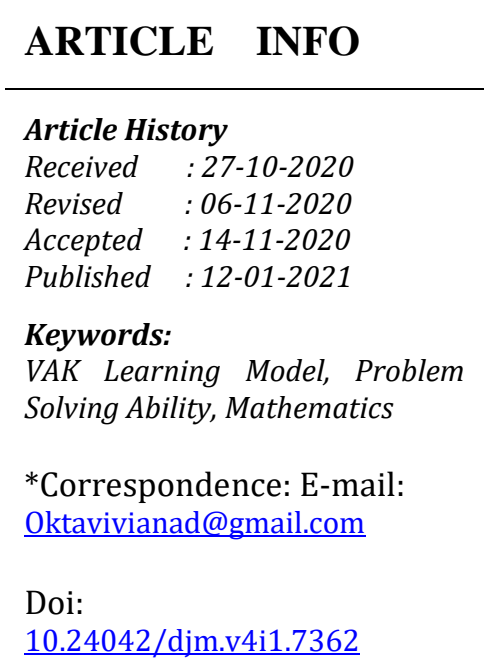

\begin{abstract}
This study aimed to determining the effect of using VAK (Visual, Auditory and Kinesthetic) learning model on the mathematics problem solving abilities. This study utilized a quantitative method with a research design Post-Test Only Control Design. The instrument is used a test of mathematics problem solving abilities that has been validated by expert lecturers. Accordingly, the data has reliable instrument. The data in the Requirements Test analysis encompassed the normality and homogeneity tests. Hence, the variance data of the group an homogeneous distribution. Besides in the Hypothesis Test utilizing the $t$-test, it was attained that $t$ count $=3.544>$ ttable $=2.001$. Accordingly, from the data of the two classes, H1 is accepted. Hence, There is a significant effect between the VAK (Visual, Auditory and Kinesthetic) learning model and the class that does not utilize it.
\end{abstract}

http://ejournal.radenintan.ac.id/index.php/desimal/index

\section{INTRODUCTION}

Problem Solving is an inseparable part of mathematics learning, so that it cannot be separated from mathematics learning (Inayah, 2018). Problem solving is considered important for studying mathematics (Pimta et al., 2009; Yazgan, 2015). Mathematics problem solving ability is a basic ability that students should have and develop as a step that initiates the idea of developing the new knowledge and mathematics skills can be also developed.

Problem solving is when students solve a problem with an understanding they already have in order to get new experiences (Priansa, 2017). When someone solve a problem, they are not only using various knowledge and rules they already have but also will find a combination in thinking that they have never had before. In accordance to indicators of problem solving ability, namely 1) Understanding the problem; 2) Plan the completion; 3) Carry out the plan; 4) Check the answers (Priansa, 2017). Mathematics learning is very helpful in stimulating the critical thinking ability of students in solving the mathematics cases through a variety of different techniques 
in every learning activities (Kowiyah, 2016). Students' perception in the ability of problem solving match their real ability to solve the problems (Hackett, 1985; Pajares \& Miller, 1997).

The ability of problem solving is considered crucial in mathematics, but in fact the learning process does not encourage the students to achieve the ability of problem solving. It is proven in the PISA 2018 survey, in the mathematics category, Indonesia was ranked 73 out of 80 countries with an average score of 379 points. Indonesia's average score was still far from China which was in first place with an average score of 591 points (Arta et al., 2020). In addition, based on the results of observations and simple interviews conducted by researchers at the research site, there are several problems, namely: 1) the mathematics scores are still below the KKM; 2) the mathematics learning process still tends to be monotonous because the learning process is only centered on the educators; 3 ) the lack of understanding the lessons. It is because the learning activities in the class, the students were less actively involved in the learning activities. 4) the low ability of problem solving, especially in mathematics subject.

Relying on the reality described above, it is necessary to held improvements so that the mathematics problem solving ability can be improved. The options that can be applied are repairing the learning process. Learning activities that are in accordance with the learning style of the students can be the solutions. Besides that, there will be effectiveness in learning so that the learning materials can be easily understood.

Each of students has varied learning habits, the classification is visual, auditory and kinesthetic learning habits. Basically, students learn through visual (something they can see or observe), auditory (something that can be heard), and kinesthetic (something they can do/move). This difference is a challenge that teachers will face in deciding the appropriate learning model so that learning activities in the classroom become varied and all the learning habits of the students can be met. One of the learning models that can be applied is VAK (Visual, Auditory, and Kinesthetic) learning model.

The VAK learning model is an example of a learning model that emphasizes that learning must use sense organs that are owned by the students (Rukmana et al., 2018). The VAK learning model is one of the learning models related to watching, listening and moving. The VAK learning model is an example of a learning model that can optimize the watching, listening and moving activities that aim to arouse enthusiasm for studying and get the maximum results (Setiawan \& Alimah, 2019). By applying the three modalities in learning activities, there will be effectiveness and the learning will not be tedious (Suroso, 2016). The combination of visual, auditory, and kinesthetic activities in the student learning activities will make it easier to understand the material presented so that the students are less likely to experience the difficulties in studying (Suryadin et al., 2017).

The results of the previous research indicate that the VAK (Visual, Auditory, and Kinesthetic) learning model can be used to improve the learning outcomes (Yayang et al., 2016; Zulfadewina et al., 2020), to improve critical thinking ability in high class (Febrilyani et al., 2019). This is because the activities used in this learning model can encourage students to have complex understanding because they have utilized their various senses. The difference between this research and the previous research is that the researchers want to describe whether the VAK (Visual, Auditory, and Kinesthetic) learning model can be used to improve mathematics 
problem solving ability. The application of this learning model is also carried out by online class using google classroom and google meet because it is still in the covid19 pandemic period. Based on the explanation above, this research focuses on the effect of using the VAK (Visual, Auditory, and Kinesthetic) learning model on mathematics problem solving ability in the $4^{\text {th }}$ grade students of elementary school.

\section{METHOD}

The method chosen by the researchers was a quasi-experiment. This design uses an experimental group and a control group. The experimental group is a class that applies the VAK learning model, while the control group is a class that using conventional model instead of applying the VAK learning model. The learning process is carried out in accordance with government recommendations, that is the online class using google classroom and google meet. The purpose of doing online class is to break the spreading of the coronavirus disease 2019 (Covid-19). The learning was carried out three times in the experimental group and three times in the control group. After that, each group was given a post-test.

The data collection technique is in the form of a written test containing material about fractions through a posttest which will be carried out at the end of the meeting. Post-test was given to each group to determine the ability level of the students and to obtain research needs, both factual data and information about the problem faced in the research. The post-test consists of 12 questions which cover the mathematics problem solving ability that have been validated by 3 expert lecturers.

After doing the validity test using Product Moment formula, there were 10 valid questions and 2 invalid questions. The calculation of reliability was using the
Cronbach Alpha formula. The value that obtained were $r_{\text {calculated }}=0.927$ with the value of $r_{\text {table }}=0.433$. According to the results of the analysis, it is concluded that $r_{\text {calculated }}>r_{\text {table }}$ that is $0.927>0.433$, thus the problems solving instrument is reliable. The result of the calculation of the distinguishing power test of this instrument were 4 items with sufficient classification and 8 items with poor classification. While for the level of difficulty, there were 3 items with easy classification and 9 items with moderate classification.

After collecting the required data, data analysis techniques were then carried out to conclude whether the use of the VAK learning model affect the mathematics problem solving ability or not. The analysis technique includes normality using the Lilliefors test which is intended to conclude whether the observed sample distribution was from a population that is normally distributed or not. The homogeneity test used the Fisher test which is intended to find out whether the both groups have a homogeneous variance. Hypothesis testing is using the Ttest and the last one is to find how big the effect of the learning model using the Effect Size test (Sugiyono, 2018).

$$
E S=\frac{\bar{X}_{e}-\bar{X}_{c}}{S c}
$$

Description:

$$
\begin{array}{ll}
E S \quad: \quad \begin{array}{l}
\text { Effect Size } \\
\bar{X}_{e}:
\end{array} \\
\bar{X}_{c}: \begin{array}{l}
\text { The Average of post-test } \\
\text { calculation of the experimental } \\
\text { group }
\end{array} \\
\text { The Average of post-test } \\
\text { calculation of the control group } \\
\text { The post-test standard } \\
\text { deviation of control group }
\end{array}
$$

Table 1. Effect Size Criteria

\begin{tabular}{cc} 
Effect Size & Criteria \\
Coefficient & Low \\
$E S<0.2$ & Medium \\
$0.2<E S<0.8$ & High \\
$E S>0.8$ & \\
\hline
\end{tabular}


Desimal, 4 (1), 2021 - 16

Oktavia Nadia Ikawati, Kowiyah

\section{RESULTS AND DISCUSSION}

The result of the post-test for the both groups are summarized in the table as follows:

Table 2. Summary of Post-Test Data Descriptions

\begin{tabular}{lcc}
\hline Description & $\begin{array}{c}\text { Eksperiment } \\
\text { Class }\end{array}$ & Control Class \\
Highest & 100 & 89 \\
Score & 42 & 36 \\
Lowest Score & 81.26 & 69.80 \\
Average & 81.5 & 69.997 \\
(Mean) & 78.4 & 67.639 \\
Median (Me) & 143.44 & 177.76 \\
Modus (Mo) & 11.97 & 13.33 \\
Variance & & \\
Standard & & \\
Deviation $(s)$ & & \\
\hline
\end{tabular}

\begin{tabular}{lcc}
\hline Description & $\begin{array}{c}\text { Eksperiment } \\
\text { Class }\end{array}$ & $\begin{array}{c}\text { Control Class } \\
\mathrm{N}\end{array}$ \\
30 & 31 \\
\hline
\end{tabular}

Table 2 indicates that the results of the mathematics problem solving ability test between experimental group and control group are different. The experimental group has a higher result than the control group. Furthermore, to conclude whether the two observed samples were normally distributed or not, a normality test was performed using the Lilliefors test. The sample is considered normal if $L_{\text {calculated }}<L_{\text {table }}$

Table 3. Normality Test Analysis

\begin{tabular}{ccccc}
\hline Group & $\boldsymbol{L}_{\text {Calculate }}$ & $\boldsymbol{L}_{\text {table }}$ & Criteria & Normally Distributed Data \\
Experiment & 0.0926 & 0.161 & $L_{\text {Calculated }}$ & Normally Distributed \\
Control & 0.0749 & 0.159 & $<L_{\text {table }}$ & Normally Distributed \\
\hline
\end{tabular}

According to Table 3, both the experimental and control group test results are normally distributed. This is because the value of $L_{\text {calculated }}<$ $L_{\text {table. }}$. After knowing the both data distribution, the next step is testing the homogeneity of both groups using Fisher test to conclude whether the two sample groups have homogeneous variances. It is homogeneous variances if $F_{\text {calculated }}<$ $F_{\text {table }}$.

Table 4. Homogeneity Test Analysis

\begin{tabular}{|c|c|c|c|c|c|}
\hline Group & Variance & $F_{\text {calculate }}$ & $F_{\text {table }}$ & Criteria & Homogeneity Data \\
\hline $\begin{array}{c}\text { Experiment } \\
\text { Control }\end{array}$ & $\begin{array}{l}143.443 \\
177.761 \\
\end{array}$ & 1.239 & 1.85 & $F_{\text {Calculated }}<F_{\text {table }}$ & Homogeneous \\
\hline
\end{tabular}

Based on Table 4, it is indicated that both groups are homogeneous due to the value of $F_{\text {calculated }}<F_{\text {table. }}$. After both normality and homogeneity test were done as the required test for analysis, it is concluded that both groups are from populations that were normally distributed and homogeneous. Researchers can analyze the mathematics problem solving ability test of both groups by using the T-test. The criteria are accepting $\mathrm{H}_{1}$ if $t_{\text {calculated }}>t_{\text {table }}$, then there is an effect in mathematics problem solving ability by applying the VAK learning model. In addition, if $t_{\text {calculated }}<$ $t_{\text {table }}$ then $\mathrm{H}_{0}$ is accepted, it means that there is no effect on the mathematics problem solving ability test by applying the VAK learning model.

Table 5. Hypothesis Test Analysis

\begin{tabular}{ccccccc}
\hline Class & Average & Dk & $\boldsymbol{t}_{\text {Calculated }}$ & $\boldsymbol{t}_{\text {table }}$ & Criteria & Description \\
Experiment & 81.26 & 59 & \multirow{2}{*}{3.544} & 2.001 & $t_{\text {Calculated }}$ & Effected \\
Control & 69.80 & & & & $t_{\text {table }}$ & \\
\hline
\end{tabular}


Based on Table 5, there is rejection on $\mathrm{H}_{0}$ and $\mathrm{H}_{1}$ is accepted. In other word, the VAK learning model has an impact on the mathematics problem solving ability.

After knowing whether there is an effect or not from applying the VAK learning model, further calculations are needed regarding of how big the effect of the VAK learning model in the learning. Therefore, the researcher applies the Effect Size test. The calculation of the Effect Size test uses the analyzed post-test data. The average post-test of experimental group is 81.26 while the average post-test of control group is 69.80 with standard deviation of 13.13 , the ES Effect Size value is 0.9 , which if based on the Effect Size Coefficient, 0.9 was included in the high category.

Based on the results of the post-test it can be indicated that there is a difference in the average score of the ability to solve mathematics problems between the control group and the experimental group.

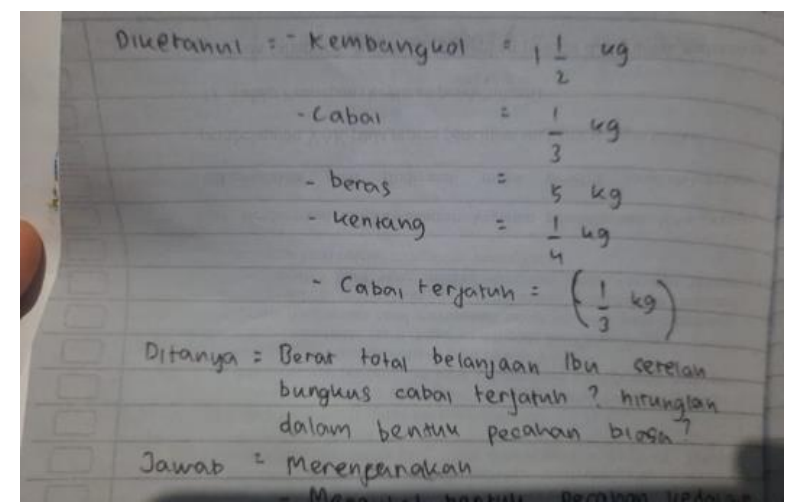

Figure 1. PD 1 Experimental Group

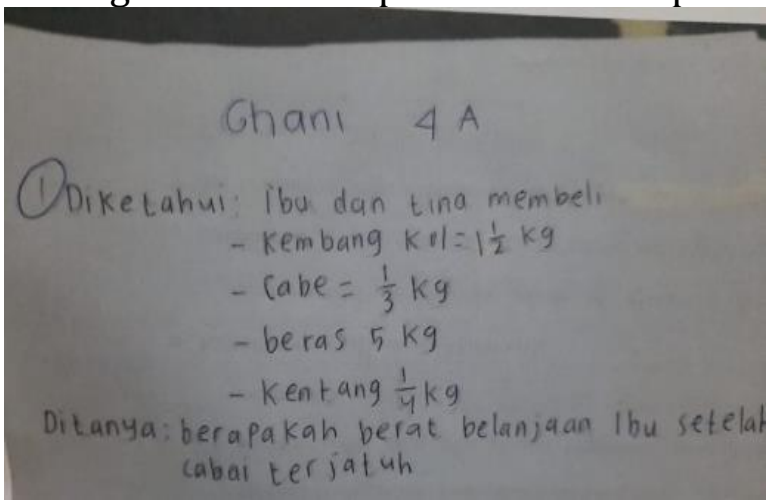

Figure 3. PD 1 Control Group
This happened because both groups are treated differently. In the experimental class, learning was implemented using the VAK (Visual, Auditory, and Kinesthetic) learning model through google classroom and google meet while the control class did not use the VAK (Visual, Auditory, and Kinesthetic) learning model.

The post-test score on fraction material between the experimental group and the control group are broadly experienced differences. The given posttest questions were 10 essay questions, which each question covering all indicators of problem-solving abilities.

The ability to solve mathematics problems in both the experimental and the control group is based on 4 indicators namely, 1) Understanding the problem; 2) Planning the completion; 3 ) Carry out the plan; 4) Check the answer. In the first indicator, students are expected to be able to write down the contained information in the questions in the form of known and asked components.

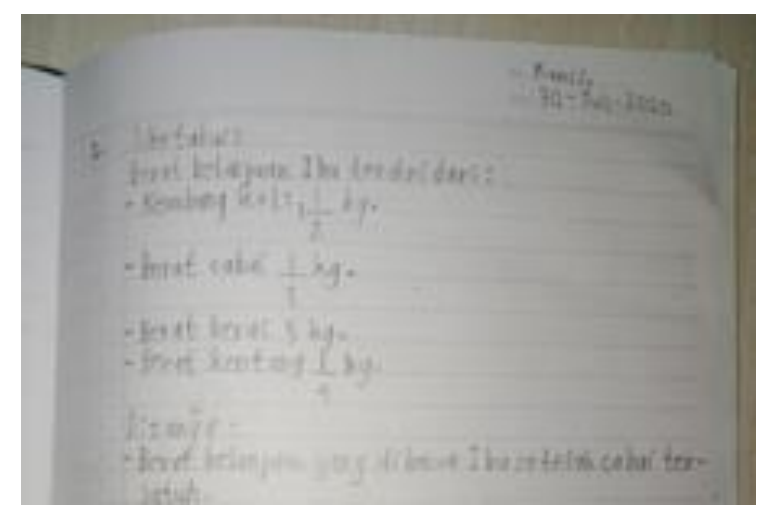

Figure 2. PD 2 Experimental Group

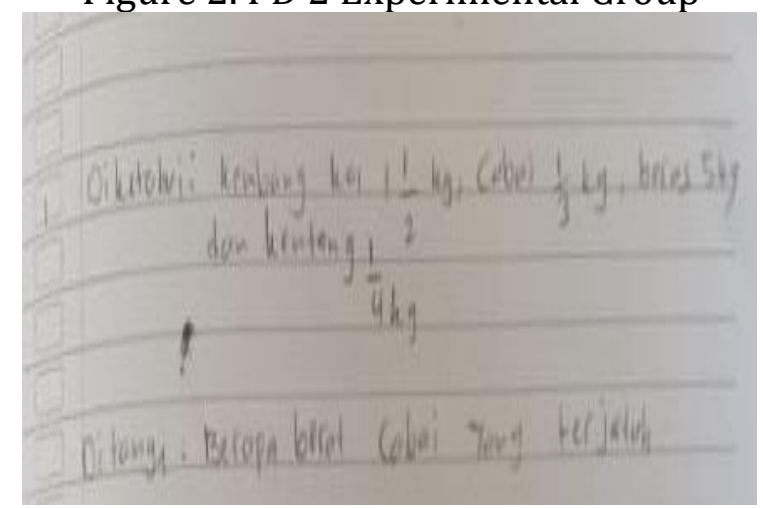

Figure 4. PD 2 Control Group 
Based on the pictures, it shows that almost all students in the experimental group were skilled in understanding the problem by writing down the known and asked components. Whereas for the control group is shown in Figure 3 and Figure 4. Figure 3 shows that PD 1 already write down the known and asked components correctly. This indicates that PD 1 in the control group can understand the problem from the question. While PD 2 in the control group already write down the known and asked components from the question, but there are still mistake and inaccurate.

On the indicator of planning the completion, students are asked to write down the steps that they used in problem solving. This can be a plan or a formula if there is a formula to be used.

On the indicator of designing the planning, the experimental group students

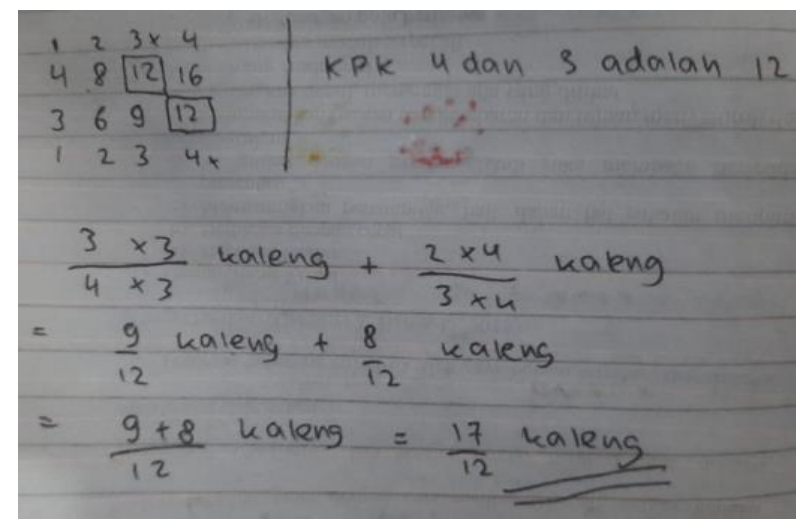

Figure 5. PD 1 Experimental Group

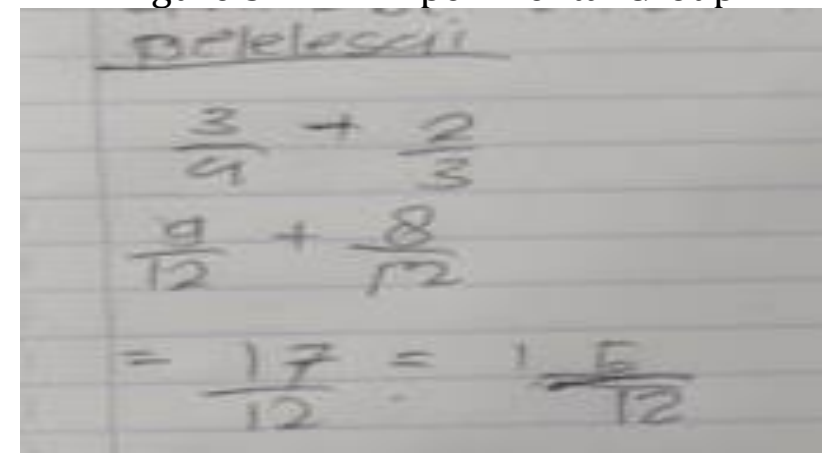

Figure 7. PD 1 Experimental Group

In the indicator of checking the answers, students are asked to doublecheck each component that has been written down. Then they must add a already be able to design to solve a problem. Meanwhile, the control group still not complete or structured yet. It is different compared to experimental group which has written in structured manner or a formula if there is a formula to be used.

On the indicator of planning the research, the experimental group students could already plan to solve a problem. Meanwhile, the control group was not completed or structured. It is different compared to experimental group that has written in structured manner. There was also student in the control group who had not written the planning completion components.

In problem solving indicator, students must carry out the plans they have made at the planning completion stage, at this stage students will count to get an answer for the question.

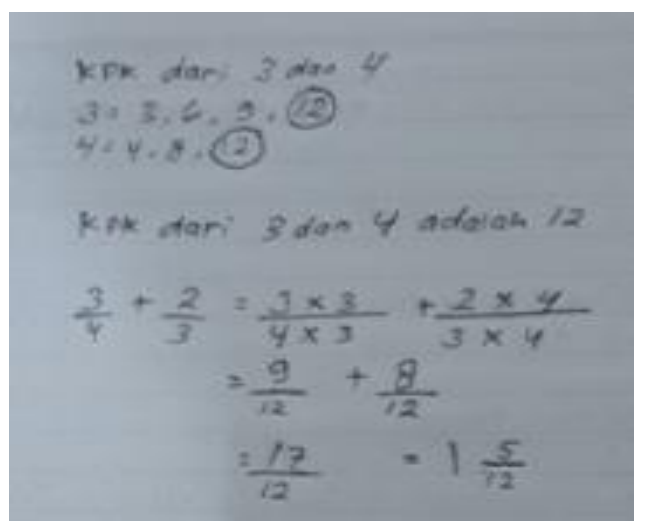

Figure 6. PD 2 Experimental Group

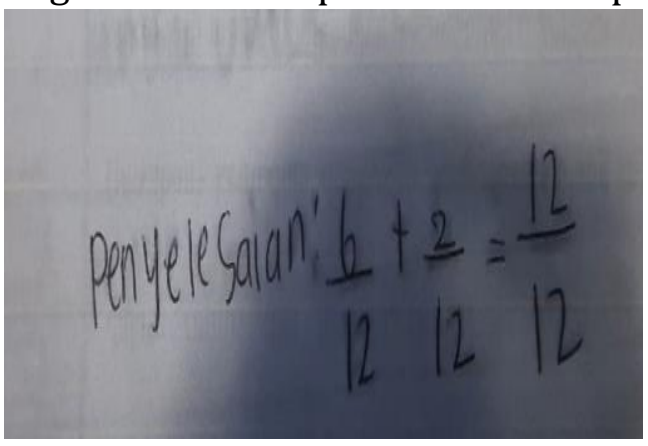

Figure 8. PD 2 Experimental Group

conclusion at the end of the answer. Based on the explanation above, it can be concluded that the use of the VAK learning model can affect students' mathematics 
problem solving abilities to be better compared to students that not using the VAK learning model in the learning process. This learning model can facilitate all learning habits and gives more learning experiences. The results of this research are reinforced by previous research which states that the use of the VAK learning model can effectively improve students' mathematics problem solving abilities. (Butar-butar et al., 2020).

\section{CONCLUSIONS AND SUGGESTIONS}

The application of the VAK (Visual, Auditory, and Kinesthetic) learning model has a significant effect on the ability to solve mathematics problem solving on fraction material. The VAK (Visual, Auditory, and Kinesthetic) learning model is very helpful in the learning process, especially in mathematics learning activities. The application of this learning model encourages the growth of students' interest in the mathematics learning and the material can be deeply understood until finally came the ability of problem solving on the questions given. The VAK (Visual, Auditory, and Kinesthetic) learning model can also make mathematics learning is more meaningful because students take an active role in the learning that combines the three learning styles they have, for example watching, listening and doing.

Based on the result that found in the research site, research suggest that before educators use the VAK (Visual, Auditory, and Kinesthetic) learning model in the learning activities, they must be well prepared in order to get the maximum results. By doing this research, it may give benefits for educators and students.

\section{REFERENCES}

Arta, Japa, \& Sudarma. (2020). Problem based learning berbantuan icebreaker berpengaruh terhadap kemampuan pemecahan masalah matematika. Mimbar PGSD Undiksha,
8(2), 264-273.

Butar-butar, G. R. M., Ardiana, N., \& Lubis, R. (2020). Efektifitas penggunaan model pembelajaran visualization auditory (VAK) terhadap kemampuan pemecahan masalah tematis siswa. JURNAL MathEdu (Mathematic Education Journal), 3(3), 28-34.

Febrilyani, W. L., Nurochmah, A., \& Sutisnawati, A. (2019). Pengaruh model pembelajaran visual-auditorykinesthetic (VAK) terhadap kemampuan berpikir kritis di kelas tinggi. Caruban, Jurnal Ilmiah Pendidikan Dasar, 2(2), 102-114.

Hackett, G. (1985). Role of mathematics self-efficacy in the choice of mathrelated majors of college women and men: A path analysis. Journal of Counseling Psychology, 32(1), 47.

Inayah, S. (2018). Peningkatan kemampuan pemecahan masalah dan representasi multipel matematis dengan menggunakan model pembelajaran kuantum. KALAMATIKA Jurnal Pendidikan Matematika, 3(1), 1-16. https://doi.org/https://doi.org/10.2 2236/KALAMATIKA.vol3no1.2018p p1-16

Kowiyah. (2016). Peningkatan kemampuan berpikir kritis dalam pemecahan masalah matematis menggunakan pendekatan open ended. Jurnal Inovasi Pendidikan Dasar, 5(1), 67-74. https://doi.org/https://doi.org/10.2 2236/jipd.v1i2.19

Pajares, F., \& Miller, M. D. (1997). Mathematics self-efficacy and mathematical problem solving: implications of using different forms of assessment. The Journal of Experimental Education, 65(3), 213228.

https://doi.org/10.1080/00220973. 1997.9943455

Pimta, S., Tayruakham, S., \& 
Desimal, 4 (1), 2021 - 20

Oktavia Nadia Ikawati, Kowiyah

Nuangchalerm, P. (2009). Factors influencing mathematic problemsolving ability of sixth grade students. Journal of Social Sciences, 5(4), 381385.

Priansa, D. J. (2017). Pengembangan strategi dan model pembelajaran: inovatif, kreatif, dan prestatif dalam memahami peserta didik (Cetakanke). CV PUSTAKA SETIA.

Rukmana, W., Hardjono, N., \& Aryana, A. (2018). Peningkatan aktivitas dan hasil belajar dengan model pembelajaran vak berbantu media tongkat tokoh. Journal of Education Action Research, 2(3), 157-164. https://doi.org/10.23887/jear.v2i3. 16255

Setiawan, A., \& Alimah, S. (2019). Pengaruh model pembelajaran visual auditory kinesthetic (VAK) terhadap keaktifan siswa. Profesi Pendidikan Dasar, 1(1), 81-90. https://doi.org/10.23917/ppd.v1i1. 7284

Sugiyono. (2018). Metode penelitian pendidikan pendekatan kuantitatif, kualitatif, dan R\&D. In Alfabeta (cetakan ke). Alfabeta.

Suroso. (2016). Peningkatan daya ingat terhadap pelajaran matematika melalui penggunaan media pembelajaran. Jurnal Sigma, 1(2), 41-
46.

Suryadin, Merta, I. W., \& Kusmiyati. (2017). Pengaruh model pembelajaran visual auditorial kinestetik (VAK) terhadap motivasi dan hasil belajar IPA biologi siswa kelas VIII SMP Negeri 3 Gunungsari Tahun Ajaran 2015/2016. Jurnal Pijar MIPA, 12(1), 19-24. https://doi.org/http://dx.doi.org/10 .29303/jpm.v12i1.330

Yayang, A., Alditia, T., Gusrayani, D., \& Panjaitan, R. L. (2016). Pengaruh model visual, auditory, dan kinesthetic (VAK) terhadap hasil belajar siswa pada materi sifat-sifat cahaya. Jurnal Pena Ilmiah, 1(1), 351360.

https://doi.org/10.23819/pi.v1i1.30 41

Yazgan, Y. (2015). Sixth grader and nonroutine problems: Which strategies are decisive for success? Educational Research and Reviews, 10(13), 1807-1816.

Zulfadewina, Iba, K., \& Noviyanti, I. (2020). Pengaruh model pembelajaran visual, auditori, dan kinestetik (VAK) terhadap hasil belajar IPA peserta didik kelas IV di SDN Pondok Kopi 07 Pagi Jakarta Timur. Jurnal Elementaria Edukasia, 3(2), 355-364. 